\title{
Drivers of Productivity: a Case Study of the Australian Construction Industry
}

\author{
Will Chancellor \\ Australian Bureau of Statistics, Melbourne, Australia
}

\begin{abstract}
Australian construction productivity has grown slowly since 1985 and remained arguably stagnant. The importance of this study was therefore to examine several drivers of construction productivity and to understand possible avenues for improvement. The drivers tested at the national level were research and development, apprentices, wage growth, unionisation and safety regulation. Selection of these drivers was based on previous construction and productivity research. Wages and research and development expenditure were found to drive construction productivity at the national level and expenditure on research and development and the number of apprentices were found to be drivers of construction productivity in Victoria, New South Wales and Western Australia. These findings are important since these three states collectively account for a majority of construction activity in Australia.
\end{abstract}

Keywords: Construction, productivity, DEA, Australia.

Paper type: Research article

\section{Introduction}

The decision to focus on the productivity drivers began with the perception of slow productivity growth in the Australian construction industry, as indicated in official statistics (Australian Bureau of Statistics, 2013a). The measurement of productivity growth does however continue to be a controversial topic, with some research concluding strength in the Australian construction industry. Toner et al. (2001) undertook an international comparison and found that Australia had one of the most productive construction industries in the world and was "within the top three OECD countries in terms of construction output per person employed" (Toner et al., 2001, p.104). Such comparisons are often faced with measurement challenges including the comparability of international data, exchange rate fluctuations and purchasing power differences. A recent Productivity Commission inquiry into Australian construction industry productivity found growth to be 'sluggish' and not significantly different from other developed countries (Productivity Commission, 2014).

This paper begins with productivity growth for Australian construction at the national level, and then produces more detailed state level estimates. National construction industry analysis was advantageous in that improved data availability allowed for long time series analysis. Conversely, state based construction data availability dictated a shorter time series analysis, however allowed for a segmented analysis of the Australian construction industry. These productivity estimates were derived using Färe-Primont Data Envelopment Analysis (DEA) based Total Factor Productivity (TFP) as in O'Donnell, (2011) and O’Donnell, (2014). A multiple linear regression

\footnotetext{
Copyright: Construction Economics and Building 2015. (C) 2015 Will Chancellor. This is an Open Access article distributed under the terms of the Creative Commons Attribution 4.0 Unported (CC BY 4.0) License (https://creativecommons.org/licenses/by/4.0/), allowing third parties to copy and redistribute the material in any medium or format and to remix, transform, and build upon the material for any purpose, even commercially, provided the original work is properly cited and states its license.
}

Citation: Chancellor, W., 2015. Drivers of productivity: a case study of the Australian construction industry, Construction Economics and Building, 15(3), 85-97. DOI: http://dx.doi.org/10.5130/AJCEB.v15i3.4551

Corresponding author: Will Chancellor; Email - will.chancellor11@gmail.com

Publisher: University of Technology Sydney (UTS) ePress 
method was then used to test these productivity estimates against several driver variables identified.

Using productivity growth as the dependant variable and the productivity drivers as independent variables, it was possible to test the correlation significance and the amount by which an apparent driver influenced the national construction productivity from 1985 to 2012 and state productivity from 1990 to 2012. It was also possible to test whether the directional influence was positive or negative, and hence, whether a tested driver was improving or impeding productivity growth. Analysis in this paper focused on measurable factors at the national and state levels however, in reality there are a number of detailed firm level factors that may affect efficiency and productivity such as communication, quality of management, rework and logistical issues. Aggregated state and national level data for these factors was not available and therefore these possible firm level drivers were not considered in the analysis. Furthermore the focus of this study was at industry level and therefore the inclusion of firm level factors was considered outside the scope.

\section{Background}

Australian construction productivity research often focuses on measurement issues such as failure to incorporate quality improvements, data limitations, and varying opinions surrounding the most appropriate estimation methods (Parham and Zheng 2006; Hughes and Thorpe 2014; Toner et al., 2001; McGrath-Champ, Rittau and Rosewarne, 2010). The factors that influence productivity growth are also regularly discussed at both macroeconomic and microeconomic levels, often with limited empirical evidence. These discussions tend to be focused on hypothetical or theoretical contexts.

Due to the diverse mixes and scales of productive activity in the different states of Australia, research isolated to the national level provides only a partial explanation of productivity. In addition, the vastly different geographical sizes and locations of the Australian states are expected to influence productivity growth and respective productivity drivers. Consider the construction industry in Western Australia which has a high level of heavy and civil engineering construction activity generated to support strong mining industry growth. Conversely, consider the Tasmanian construction industry, which is small and isolated with a mix of building and engineering construction.

Productivity growth estimates for the Australian construction industry, particularly at a subdivision or state level were only identified in several papers. For example, Li and Liu (2010) measured productivity growth at the national and state level for the Australian construction industry. Using Australian Bureau of Statistics data items they applied a Malmquist DEA method to conclude slow productivity growth for the Australian construction industry from 1990 to 2007. They also touched on drivers of productivity growth in Australian construction, mentioning that improvements in mechanical equipment and construction technology might promote productivity improvement.

$\mathrm{Li}$ and Liu (2010) experimented with the decomposition of Malmquist indexes using Australian Bureau of Statistics data items. Their study used a decomposition approach to estimate Malmquist productivity indexes and technical change indexes for the Australian construction industry in each state and territory. They found 'no obvious difference' in the growth speeds of construction productivity in Australian states. To find more obvious results, Li and Liu (2010) aggregated the states into regions, where the eastern region included Australian Capital Territory, New South Wales, Victoria, Queensland and Tasmania, the middle region included Northern Territory and South Australia, and the western region included Western Australia only. When observing Malmquist productivity indexes for the construction industry by region rather than 
state, they found that technical progress was a productivity driver in the middle region and that technical efficiency was a driver in the eastern region.

As was the case in this research, Chancellor and Abbott (2015) applied the Färe-Primont DEA based method to derive productivity estimates for the Australian construction industry. Their results indicated slow national level construction productivity growth from 1985 to 2012. A similar method was applied in Chancellor, Abbott and Carson (2015) in their comparative study of the Australian and New Zealand construction industries, using DEA to obtain productivity estimates for the Australian construction industry at state level using engineering and nonresidential expenditure and residential floor space as outputs, and construction labour and construction capital as inputs. They identified the importance of state level productivity analysis and the need to understand the drivers of construction productivity.

Selection of productivity drivers was based on previous construction and productivity research. Davis (2007) for example identified drivers of New Zealand construction productivity as regulation, investment, competition, innovation, enterprise and skills. Construction productivity drivers were also considered by Jansen and McLoughlin (2008) to be innovation, skills, investment and regulation. Similarly Budiawan and Sidwell (2004) identified innovation as a driver of construction productivity. Unionisation was identified by Doucouliagos and Laroche (2004) and Maki (1983) as having a relationship to construction productivity however the direction of this relationship varies between positive and negative. Davis (2007) similarly discussed that increased stringent safety requirements, union activities and days lost due to industrial action impacted productivity growth in the New Zealand construction industry. The variables to be tested at the national level were therefore decided as research and development, apprentices, wage growth, unionisation and safety regulation. As wage growth and safety regulation data was not available at state level these variables were confined to the national level analysis.

\section{Methodology and data}

In order to test the independent driver variables with relation to the dependent productivity variable, productivity growth for the Australian construction industry was estimated at both the national and state levels. While it would have been possible to use Australian Bureau of Statistics construction industry productivity estimates at the national level, these same industry estimates were not available at the state level (Australian Bureau of Statistics, 2013a). So that estimates followed a consistent method, both national and state level construction industry productivity growth was calculated in the paper using Färe-Primont DEA based TFP as in O'Donnell (2011) and O’Donnell (2014).

The Färe-Primont method was used in this research due to the advantages it has over the commonly used Malmquist method. As explained in O'Donnell (2012), the Färe-Primont method satisfies economic and mathematical assumptions such as inactivity, transitivity and boundedness (O'Donnell, 2012). O'Donnell (2011) highlights that the Laspeyres, Paasche, Fisher, Malmquist and Hicks-Moorsteen indexes all fail the transitivity test and should be used for single binary comparisons rather than multiple comparisons with decomposition. These popular indexes have been commonly applied by a number of researchers in the past (Chau 2003, Xue, et al. 2008; Tan, 2000; Li and Liu, 2010). As the productivity in this paper uses multiple comparisons and is decomposed into technical and scale efficiency, the Färe-Primont was decided to be suitable.

In estimating the national level construction industry productivity growth; capital stock and hours worked were the respective inputs and industry Gross Value Added (GVA) was the respective output. This data is available in Australian Bureau of Statistics catalogue number 5204.0 - Australian System of National Accounts, from 1985 to 2012. The estimation of state level 
construction industry productivity growth used construction work done as the capital input, number of construction employees as the labour input, and industry GVA as the respective output (ABS, 2012a; ABS, 2012b; ABS, 2012c). Capital stock was not available at state level by industry and therefore construction work done was found to be the most suitable alternative capital input. This input and output configuration was also used by Li and Liu (2010) in their state level Malmquist DEA based TFP estimation of the Australian construction industry.

These national and state level input and output data sets were arranged into a panel data format, and then loaded to software DPIN version 3.0 as discussed in O'Donnell (2011). This software uses a linear programming method to construct a frontier over data points as proposed by Farrell (1957) and allows for the specification of particular commands. For the purposes of this analysis the following commands were selected: Färe-Primont index; variable returns to scale; unit means; and technical regress allowed. This configuration removed restrictions such as constant returns to scale, which is not necessarily indicative of real world production activity.

To derive actual productivity estimates, Equation 1 was used. Mathematically, it represented TFP as an aggregation of outputs divided by an aggregation of inputs over time.

$$
T F P_{\mathrm{t}} \equiv \frac{Q_{\mathrm{t}}}{X_{\mathrm{t}}}
$$

Where:

$$
\begin{aligned}
& Q=\text { Aggregate output } \\
& X=\text { Aggregate input } \\
& t=\text { Time period }
\end{aligned}
$$

In order to produce a productivity time series, an appropriate index number method needed to be specified. There were a number of index number options available, of which the FärePrimont index was determined to be the most suitable. This multiplicatively complete index number method was applied in DEA based software to estimate TFP and various measures of efficiency for the Australian construction industry at the national and state levels (O'Donnell, 2014). For ease of explanation, Equation 2 represents TFP within a multiple comparison aggregated time series structure.

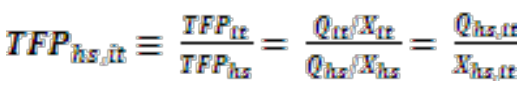

Where:

$Q_{\text {hait }}=$ Output quantity index

$\mathcal{X}_{\text {hag }}$ it $=$ Input quantity index

A time series of technical and scale efficiency was derived using DEA, which resulted in a value between zero and one for each year from 1985 to 2012. A value of one indicated that the observation was on the DEA frontier. This meant that the industry demonstrated full technical efficiency for the respective period. Efficiency level refers to a value of between zero and one for a given time period increment; where zero was an indication of full inefficiency and one was an indication of full efficiency. Within the context of this research, technical efficiency was the ability of the construction industry to obtain maximum Gross Value Added from labour and 
capital inputs. Input technical and scale efficiency were examined, rather than output efficiency, as construction firms tend to have more control over their labour and capital inputs than their outputs. Scale efficiency is defined as a measure of whether the construction industry was operating at an optimal scale. The variable returns to scale assumption was applied as it allows for a more accurate representation of real world conditions, revealing periods of technical inefficiency experienced by the Australian construction industry. Without the variable returns to scale assumption, this inefficiency may have been hidden.

The next phase of the methodology was to specify the independent driver variables. The drivers tested at the national level were: construction apprentices as a percentage of the construction workforce, construction average weekly earnings, construction expenditure on research and development as a percentage of construction GVA, construction union members as a percentage of the construction workforce, and the number of construction serious injury claims. For the state level analysis the drivers tested were: construction apprentices as a percentage of the respective state or territory construction workforce, state level construction expenditure on research and development as a percentage of state level construction GVA, and state level construction union members as a percentage of state level construction workforces. These independent driver variables are presented in Table 1.

Table 1: Independent variable data descriptions ${ }^{1}$

\begin{tabular}{ll}
\hline Independent variable & Data description \\
\hline Apprentices & Construction apprentices as a percentage of the national construction workforce. \\
Wages & Construction industry average weekly earnings \\
Research and development & Expenditure on construction industry research and development as a percentage of \\
& construction industry GVA. \\
Unionisation & Total number of construction industry union members by state \\
Safety regulation & A count of construction industry serious injury claims per year over time. \\
\hline
\end{tabular}

All driver data items tested were specific to the construction industry. The regression analysis used national and state construction productivity estimates as the dependent variables, and regressed these to the independent variables driver variables. The significance of a tested driver was established to determine whether that driver actually influenced construction productivity in a given state or at the national level. It was also possible to determine the influential direction of each tested driver as either having a positive or negative effect on construction productivity. The regression was completed using SPSS. Independent driver variables $(\mathrm{x})$ were associated with the dependent productivity variable (y). As in Yale (1997), the multiple linear regression was formally represented in Equation 3.

$Y=\beta_{0}+\beta_{1} X_{1}+\beta_{2} X_{2}+\cdots \beta_{i} X_{i}+e$ for $i=1,2, \ldots n$

The national level regression analysis was therefore represented in Equation 4:

National productivity $=\beta_{0}+\beta_{1}$ (Apprentices) $+\beta_{2}($ Wages $)+\beta_{a}$ (R\&D) $+\beta_{4}$ (Unionisation) + $\beta_{5}($ Saf ety regulation) $+e$

The state level regression analysis was represented in Equation 5:

State productivity $=a_{0}+a_{1}$ (Apprentices) $+a_{2}($ R\&D $)+a_{n}($ Unionisation $)+e_{1}$

${ }^{1}$ Wages and safety regulation used for the national level analysis only 
In testing whether an independent productivity driver variable had a significant correlation to the respective dependent productivity variable, a p-value of less than 0.05 was defined as a statistically significant. Note that the regression method uses a two tailed test. To evaluate whether an independent driver variable had a positive or negative correlation to the dependent productivity variable, standardised estimates were used to produce regression weights. These regression weights also provided an indication of the extent by which a significant independent driver variable affected the dependent productivity variable.

\section{Results}

The national level productivity findings in this paper indicated that construction productivity growth in Australian construction appeared to be growing slowly. Results in Figure 1 suggested gradual productivity growth for the Australian construction industry from 1985 to 2012. Note the disruption to the time series from 2000 to 2002, caused by the introduction of the Australian Goods and Services Tax system which influenced the timing of construction activity (Australian Bureau of Statistics, 2007). From 2002 onwards, national productivity in Australian construction achieved gradual improvement only.

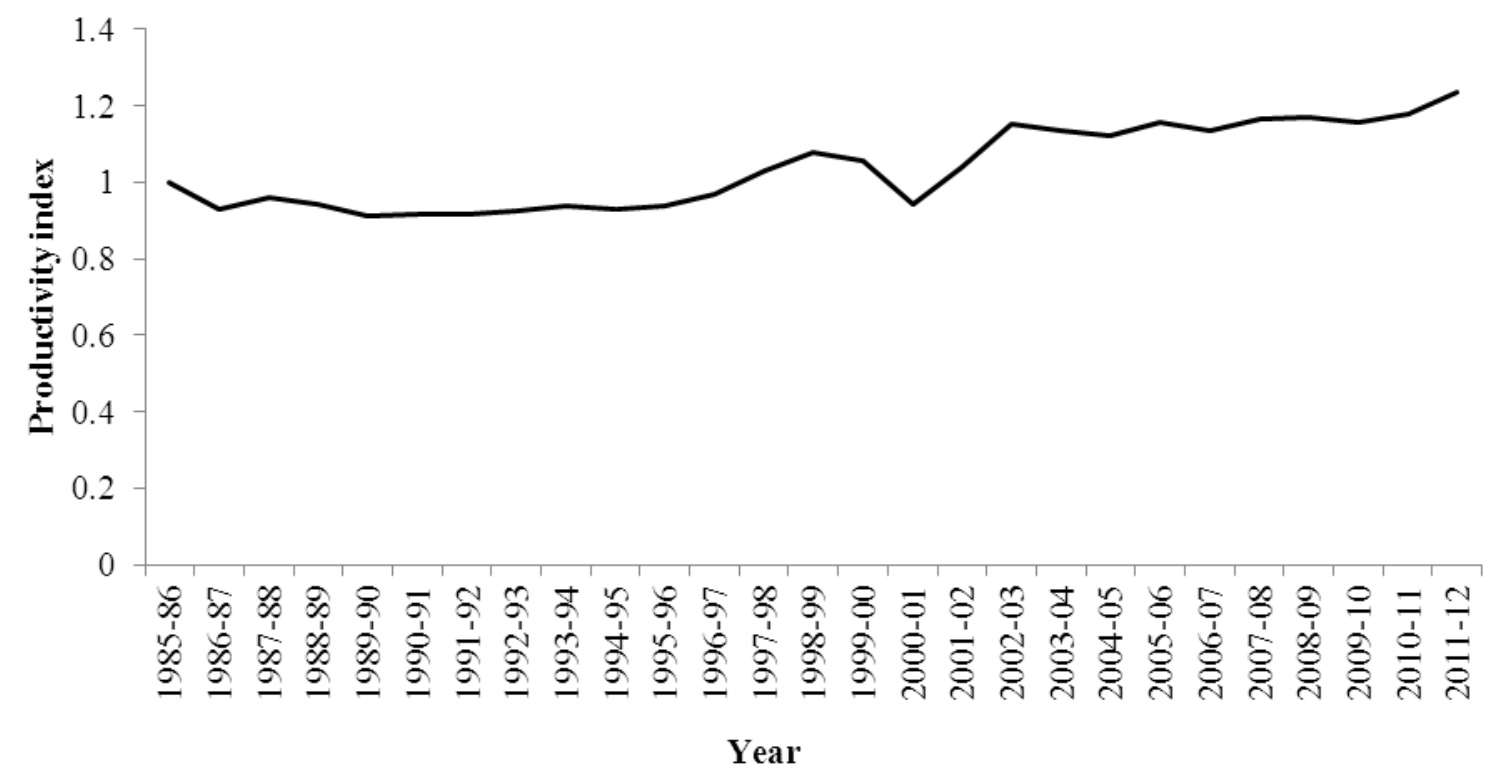

Figure 1: National level construction productivity

Data source: Original data sourced from Australian Bureau of Statistics Cat. No. 5204.0 (Tables 5, 15, and 58) (Färe-Primont $D E A$ based TFP, base year $=1985$ )

Controversy surrounds the reasons for this slow growth. One view is that change in construction quality is not captured and used to adjust output (Rosefielde and Mills, 1979). Therefore if construction quality had improved over time and was considered to be a component of productivity growth, then stagnation may not accurately reflect the industry. Another argument was raised by Allen (1985) who considered the construction industry to be predominantly labour intensive, and that increased output resulting from innovative and technological improvement was restricted by a given level of labour and capital. It was also possible that the Australian construction industry had entered a point of high efficiency, where productivity growth was no longer easily obtainable. To explore this further, input technical efficiency and input scale efficiency levels were added and represented in Figure 2. 
In reference to Figure 2, the construction industry did appear to have reached a point of full technical and scale input efficiency in 2011-12. This emphasised the importance of exploring possible productivity drivers so that avenues for productivity improvement become visible. It also had implications for construction managers, in that peak technical and scale efficiency suggest future productivity gains will be more difficult to achieve. Managers will need to exhaust all avenues of possible productivity improvement.

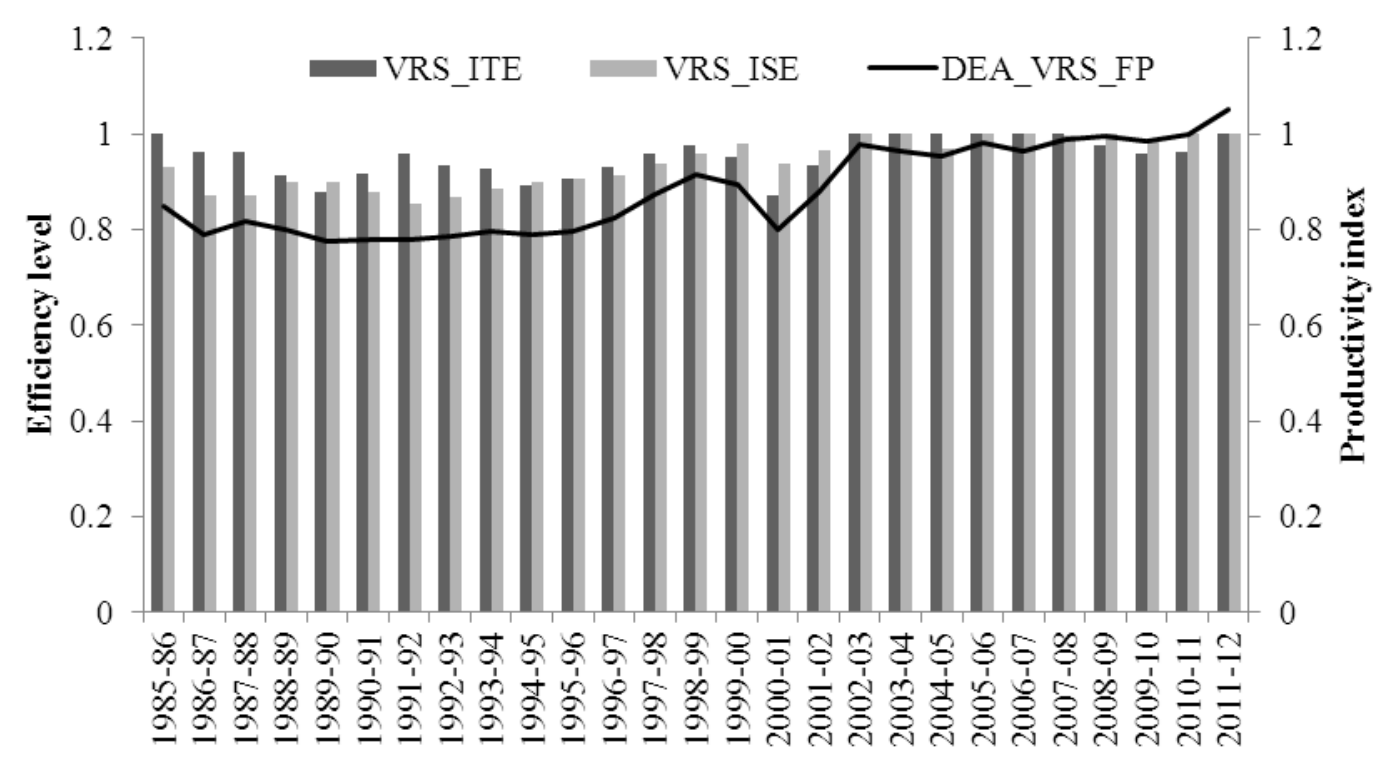

Year

Figure 2: National level construction productivity and efficiency ${ }^{2}$

Data source: Original data sourced from Australian Bureau of Statistics Cat. No. 5204.0 (Tables 5, 15, and 58) (Färe-Primont $D E A$ based TFP, base year $=1985$ )

State level productivity results demonstrated the diversity of the Australian construction industry when observed for different geographic locations. These results also highlighted the value of analysing productivity growth at a more detailed level. While the national productivity estimates in Figure 1 demonstrated slow growth overall, the state level construction estimates in Figure 3 highlighted productivity decline in some states and productivity growth in others. These variances were possibly due to different industry mixes, differences in scale or technical efficiency, and differences in other drivers of productivity growth.

Productivity grew strongly in New South Wales construction (Figure 3) when compared to other states. The construction industry in New South Wales was a comparatively balanced mix of residential, non-residential and engineering construction. The industry mix in New South Wales was service focused, as was also the case in Victorian construction. Productivity growth in Victorian and South Australian construction followed a similarly subdued trend to national productivity in Figure 1.

Tasmania and the Australian Capital Territory both had similarly small sized construction industries and both achieved above average productivity growth in Figure 3. Construction output in both regions was low for the period measured when compared to other states. Similarly capital and labour inputs were also low, enabling satisfactory productivity growth, at least in the short to

\footnotetext{
2 VRS_ITE (Variable Returns to Scale Input Technical Efficiency), VRS_ISE (Variable Returns to Scale Input Scale Efficiency), DEA_VRS_FP (Data Envelopment Analysis Variable Returns to Scale Färe-Primont)
} 
medium term. The industry mix in Queensland was different from the previously mentioned states, due to a larger proportion of mining activity driven construction demand. It is possible that the civil engineering subdivision of construction, which was comparatively dominant in Queensland, was more productive than other construction subdivisions. Western Australia was also influenced heavily by the mining industry, with corresponding output growth from mining related construction activity. The high proportion of inputs invested in Western Australian construction appeared to have limited productivity growth in the short to medium term. Over the past ten years, this high level of capital and labour input investment in Western Australian construction has been immense when compared to other states (Australian Bureau of Statistics, 2012a). Productivity for Northern Territory construction yielded the weakest results of all states, experiencing a sharp decline from 2007 to 2012, as is illustrated in Figure 3. Examination of the input and output data indicates a sharp drop in construction GVA for the same time period. This decline in output suggests that the Northern Territory slowdown was caused by inefficiency, negative productivity drivers and general economic conditions, rather than a change in labour or capital inputs.

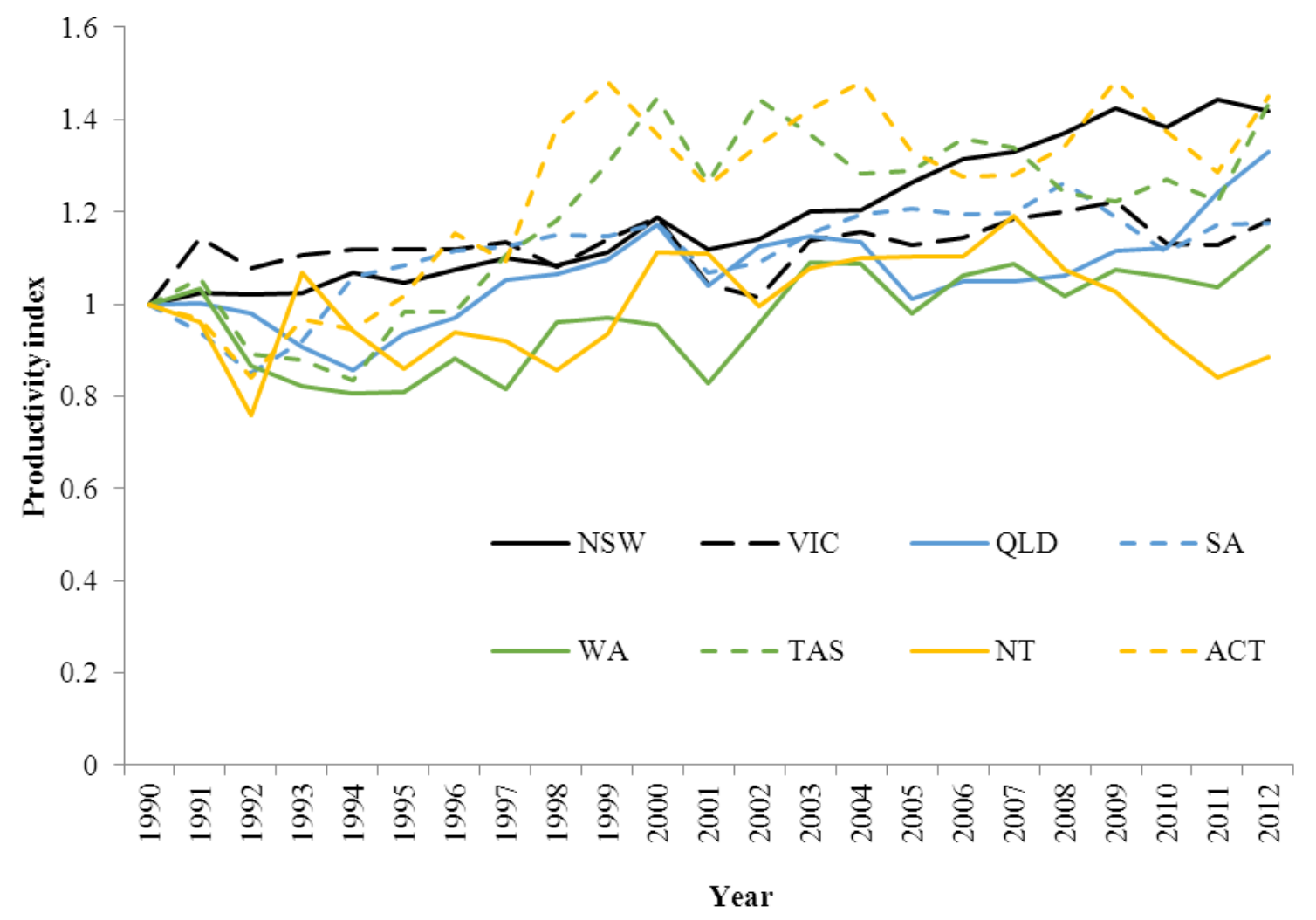

Figure 3: State level construction productivity

Data source: Original data sourced from Australian Bureau of Statistics Cat. No. 8755.0; 6291.0.55.003; 5220.0 (Färe-Primont $D E A$ based TFP, base year $=1990$ )

\section{National Productivity Drivers}

Five possible productivity drivers were tested against the national construction productivity estimates. Three of these drivers were found to have a significant correlation to the national construction productivity growth estimates. As indicated in Table 2, construction industry average weekly earnings, research and development, and construction union members were all found to be significantly correlated to the national construction productivity growth estimates. An independent driver variable is considered significant when its P-value is less than 0.05. 
Prior to completing this research, the number of construction apprentices was expected to have a positive correlation to productivity growth in Australia. This reasoning was based on the expectation that a more highly skilled and eager apprentice workforce would increase technical efficiency and construction output. These findings aligned with the work of McGrath-Champ, Rittau and Rosewarne, (2010) who considered training to be a driver of productivity growth in Australian construction. The independent driver findings in this paper concluded that apprenticeships were not significantly correlated to the national level construction industry productivity estimates.

Table 2: Regression weights for national level drivers

\begin{tabular}{lccc}
\hline Independent variable & Estimate & Standard error & P-value \\
\hline Apprentices & 3.806 & 2.893 & 0.188 \\
Wages & .000 & .000 & 0.001 \\
Research and development & .000 & .000 & 0.001 \\
Unionisation & -1.020 & .368 & 0.006 \\
Safety regulation & .000 & .000 & 0.811 \\
\hline
\end{tabular}

The average weekly earnings independent driver variable was regressed to establish whether a correlation existed between national construction productivity growth and wage growth. This driver variable focused on the labour input component of the construction productivity calculation, and was considered due to the labour intensive nature of the construction industry (Allen, 1985). Research by Meager and Speckesser (2011) also identified an empirical link between wages and productivity. This link was reinforced by the results in Table 2, which identify a significant correlation between wages and construction productivity growth.

Construction expenditure on research and development was a means of testing for innovation, which is often considered by researchers to be a driver of productivity growth (Färe et al., 1996; Davis, 2007; Budiawan and Sidwell, 2004). Through innovation it is possible to improve technology, processes, quality of construction, and technical efficiency. By comparison to other Australian industries, construction industry expenditure on research and development was minimal in the 1980s and 1990s (Australia Bureau of Statistics, 2013b). The regression results in Table 2 indicate that research and development expenditure was significantly correlated to Australian construction productivity growth at the national level. These results therefore suggested that innovation was a driver of construction productivity growth in Australia.

The unionisation independent variable was used to test the unknown and controversial relationship between the number of construction union members and productivity growth at the national level. This controversy was evident in Toner et al., (2001), who were critical of the Productivity Commission (1999) in their argument that high levels of construction unionisation is adverse for productivity growth. Toner et al., (2001) also argued that the methodology used by the Productivity Commission (1999) was "flawed and incapable of demonstrating a negative link between union presence and productivity in Australian construction" (Toner et al., 2001, p.121). Due to this controversy, it was initially unknown whether construction unionisation would have a positive or negative correlation to productivity growth, with differing views identified in previous research. In a previous study by Doucouliagos and Laroche (2004), unionisation was found to have a positive effect on productivity growth in the manufacturing and education industries. Doucouliagos and Laroche (2004) also noted the controversy surrounding this relationship in economic research. Unionisation was found to have a negative effect on productivity growth in a study undertaken by Maki (1983) who discussed some of the negative effects of unionisation on productivity growth. Maki (1983) discussed that unions may prevent employers from utilising new and more efficient production technologies in an attempt to 
protect jobs. It was also possible that unions could negotiate deals to hire more workers than were needed for a given job and applied inefficient procedures to retain more workers (Maki, 1983). As highlighted by Toner et al. (2001), the Productivity Commission (1999) also discussed unionisation as being detrimental to Australian construction productivity and innovation. The Productivity Commission (1999) discuss that unionisation reduced flexibility and therefore impeded productivity growth. The regression results in Table 2 indicate that construction unionisation had a significant correlation to the national productivity growth estimates. The direction of this effect was negative, meaning that an increase in the number of construction union members had a significant and negative effect on the national construction productivity growth. These findings coincide with the research of the Productivity Commission (1999) and Maki (1983). It is possible that this negative correlation had been caused by restrictive work practices, excessive regulation, obstructions to innovation and a reduced pace of work (Maki 1983; McKersie and Klein, 1983; Productivity Commission, 1999).

The regression results from Table 2 were unable to identify a significant correlation between productivity growth and construction safety regulation. These results concluded that health and safety regulation was not a significant driver of construction productivity growth. From these results, it was also possible to conclude that health and safety initiatives had not been detrimental to construction productivity growth, despite the perceived regulatory burden. This also suggested that there was no productivity disincentive for construction employers to implement and uphold high occupational health and safety standards. The relationship between Australian construction productivity growth and safety regulation was considered by Toner et al. (2001), who discussed that while reduced safety standards might have led to short term productivity gains, the long term costs associated with injuries were not justifiable.

\section{State productivity drivers}

Given that the Australian construction industry differs at state level by geographical size and construction activity mix, it was expected that the drivers of productivity growth also differed. It was therefore important to test state level independent driver variables against state level construction productivity estimates produced earlier. This state level driver analysis had the added advantage of indicating subdivision level construction productivity drivers. It was expected that the driver results from Western Australian and Queensland construction would provide an indication of the productivity drivers in the heavy and civil engineering construction subdivision, since this subdivision was prominent in these two states. Conversely, the productivity driver results from Victoria and New South Wales provided an indication of the construction productivity drivers in the building construction and construction services subdivisions.

Table 3: Significant driver comparison ${ }^{3}$

\begin{tabular}{lccc}
\hline & Apprentices & Research and Development & Unionisation \\
\hline New South Wales & 0.911 & 0.983 & -0.997 \\
Victoria & 0.890 & 0.752 & \\
Queensland & & & 0.963 \\
South Australia & 0.890 & 0.697 & \\
Western Australia & 0.871 & 0.902 & 0.978 \\
Tasmania & & & 0.561 \\
Northern Territory & & $\mathrm{n} / \mathrm{a}$ & \\
Australian Capital Territory & & & \\
\hline
\end{tabular}

${ }^{3}$ Values left blank where $\mathrm{P} \geq 0.05$, indicating no statistical significance 
Table 3 indicates the significance and direction of state level construction productivity drivers. The summarised results from the national analysis were also included as a basis for comparison. Due to data limitations, safety regulation and wages were not included in the state level analysis. Blank values indicate that no statistical correlation was identified.

The number of construction apprentices had a significant and positive correlation to productivity growth in New South Wales, Victoria, South Australia and Western Australia. The most probable explanation is that an increase in apprentices results in a more highly skilled workforce, generating improvements in technical efficiency and subsequently, long-term productivity growth (McGrath-Champ, Rittau and Rosewarne, 2010). The correlation between apprentices and productivity growth was expected, despite not being visible during the national level analysis in Table 2. In addition to identifying apprentices as a driver of productivity growth in certain Australian states, the analysis in Table 3 demonstrates the importance of state level productivity analysis. Without this more detailed level of analysis, it would not have been possible to identify a correlation between apprentices and productivity growth.

Expenditure on research and development was designed to test whether innovation was a driver of productivity growth for the Australian construction industry at state level. It was not possible to include the Northern Territory in this section of the analysis due to exceptionally low levels of construction research and development expenditure. Innovation was found to be significantly correlated to productivity growth in New South Wales, Victoria, South Australia and Western Australia. For all significant correlations, the standardised regression estimate was positive, indicating that innovation did lead to improvements in construction productivity growth.

The national level analysis in Table 2 indicates that unionisation had a negative correlation to construction productivity growth, meaning that an increase in the number of construction union members led to a decrease in productivity growth. The results in Table 3 however, indicate a mixed result, again demonstrating the importance of detailed state level analysis. Unionisation was found to be significantly correlated to productivity growth in New South Wales, South Australia, Northern Territory and Australian Capital Territory. As with the national level analysis, the correlation in New South Wales was found to be negative. Possible reasons for this negative relationship were discussed in the national level analysis and supported by findings in Maki (1983) and Productivity Commission (1999). By contrast, the correlation between unionisation and productivity in South Australia, Northern Territory and the Australian Capital Territory were all found to be positive. Toner et al., (2001) and Doucouliagos and Laroche (2004) also concluded a positive relationship between unionisation and productivity growth. Possible reasons for this correlation include improved working conditions such as job security, successful workplace bargaining and the associated improvements in morale and motivation as discussed by Doucouliagos and Laroche (2004). These mixed results at state level highlight possibility for controversy surrounding the correlation between productivity growth and unionisation in Australian construction.

\section{Conclusion}

The Australian construction industry operates differently at state level, with some states focusing heavily on building construction, and other mining driven states focusing their construction activities on heavy civil engineering. This research component demonstrated the value in estimating lower level productivity growth, and the limitation of national level productivity estimation in isolation, with a country as geographically and industrially diverse as Australia.

The use of measurable factors expressed the novel approach used in this research, and also a limitation. There are many factors that drive construction productivity, however for many of these factors, data is inaccessible. The factors selected for analysis were chosen as the best available representation of construction productivity drivers based on previous research and data 
availability. Not all factors were expected to be positive drivers of productivity either, such as unionisation or safety regulation. The inclusion of these factors provided greater insight into factors beyond those that improved productivity, to factors that potentially hindered growth.

The state based results in this paper provide an additional insight into the actual drivers of construction productivity. Note that the national results were potentially obscured by the differences in Australian construction at state level. For example, apprentices were found to be significant in New South Wales, Victoria, South Australia and Western Australia, however were not significant at the national level. This is possibly explained by the states where apprentices were not significant (Queensland, Tasmania, Northern Territory and Australian Capital Territory), resulting in an insignificant finding at the national level. Results for unionisation were mixed and inconclusive, with some negative and positive results. Finally, a correlation was identified between wage growth and productivity, however it was difficult to conclude whether causation had occurred and it is likely that wage growth had occurred as a result of productivity growth.

A limitation of this study was the inaccessibility of all possible productivity driver data items. If longer time series and more extensive independent driver variables were available it would be possible to accomplish a more robust study. Future research could attempt to obtain additional driver data items for testing, or consider testing productivity drivers at firm level using factors such as management quality, rework and regulations. It would also be possible to test productivity drivers of construction industries in other countries more diverse than Australia. Opportunities also exist to develop new methods of regression, or to refine existing methods of identifying the drivers of productivity.

\section{References}

Abbott, M. and Carson, C., 2012. A review of productivity analysis of the New Zealand construction industry. Australasian Journal of Construction and Building Economics, 12(3), pp.1-15. doi: http://dx.doi.org/10.5130/ajceb.v12i3.2584

Allen, S.G. 1985. Why construction industry productivity is declining. Review of Economic Statistics, 117(4), pp.661-65. doi: http://dx.doi.org/10.2307/1924811

ANZ, 2013. ANZ Job Advertisements, Department of Treasury and Finance. Tasmania: Economic Analysis Unit.

Australian Bureau of Statistics, 2005. ACT Stats 2005, Cat. No. 1344.8.55.001. Canberra.

Australian Bureau of Statistics, 2007. Experimental Estimates of Industry Multifactor Productivity. Cat. No. 5260.0.55.002. Canberra.

Australian Bureau of Statistics, 2012a. Construction Work Done. Cat. No. 8755.0. Canberra.

Australian Bureau of Statistics, 2012b. Labour Force Australia, Detailed Quarterly, Nov 2012. Cat. No. 6291.0.55.003. Canberra.

Australian Bureau of Statistics, 2012c. Australian National Accounts: State Accounts, 2011-12. Cat. No. 5220.0. Canberra.

Australian Bureau of Statistics 2012d, Australian System of National Accounts, cat.no. 5204, Canberra, viewed on 03/01/2013

from http://www.abs.gov.au/AUSSTATS/abs@.nsf/Lookup/5204.0Main+Features1201112?OpenDocument

Australian Bureau of Statistics, 2013a. Estimates of Industry Multifactor Productivity, 2012-13. Cat. No. 5260.0.55.002. Canberra.

Australian Bureau of Statistics, 2013b. Research and Experimental Development, Businesses, 2011-12. Cat. No. 8104.0. Canberra.

Budiawan, D. and Sidwell, A.C., 2004. Drivers of Construction Innovation. Brisbane, Australia: Construction Industry Institute.

Chancellor, W. and Abbott, M., 2015. The Australian construction industry: is the shadow economy distorting productivity? Construction Management and Economics, 33(3), pp.176-86. doi: http://dx.doi.org/10.1080/01446193.2015.1028954

Chancellor, W., Abbott, M. and Carson, C., 2015. Factors promoting innovation and efficiency in the construction industry: a comparative study of Australia and New Zealand. Australasian Journal of Construction Economics and Building, 15(2), pp.63-80. doi: http://dx.doi.org/10.5130/AJCEB.v15i2.4386

Chau, K. W. 2003, Factors Affecting the Productive Efficiency of Construction Firms in Hong Kong, CIB TG 23 International Conference, October 2003, Hong Kong

Davis, N., 2007. Construction Sector Productivity Scoping Report. Wellington: Martin Jenkins. 
Doucouliagos, C. and Laroche, P., 2004. The Impact of U.S. Unions on Productivity: A Bootstrap Meta-Analysis. Deakin, Australia: School of Economics.

Färe, R. and Primont, D., 1995. Multi-output Production and Duality: Theory and Applications. Boston: Kluwer Academic Publishers. doi: http://dx.doi.org/10.1007/978-94-011-0651-1

Fare, R., Grosskopf. S., and Margaritis, D. 1996, A Study of Economic Reform: The Case of New Zealand Chapter 3 Productivity Growth, Elsevier Science B.V.

Farrell, M., 1957. The measurement of productive efficiency. Journal of the Royal Statistical Society, 120(3)pp.253-81. doi: http://dx.doi.org/10.2307/2343100

Hughes, R. and Thorpe D., 2014. A review of enabling factors in construction industry productivity in an Australian environment. Construction Innovation, 14(2), pp.210-228. doi: http://dx.doi.org/10.1108/CI-03-2013-0016

Jansen, J. and McLoughlin, S., 2008. New Zealand's Productivity Performance. Wellington: New Zealand Treasury.

Li, Y. and Liu, C., 2010. Malmquist Indices of Total Factor Productivity Changes in the Australian Construction Industry. Construction Management and Economics, 28, pp.933-45. doi: http://dx.doi.org/10.1080/01446191003762231

Maki, D., 1983. Trade Unions and Productivity: Conventional Estimates. Relations industrielles/Industrial Relations, vol. 38(2), p.211-88.

McGrath-Champ, S., Rittau, Y. and Rosewarne, S., 2010. Education, skill and unions in the Australian construction industry. Labour and Industry, 21(1), pp.438-62. doi: http://dx.doi.org/10.1080/10301763.2010.10669413

McKersie, R. and Klein, J., 1983. Productivity: The Industrial Relations Connection. National Productivity Review, 3(1), pp.26-35. doi: http://dx.doi.org/10.1002/npr.4040030104

Meager, N. and Speckesser, S., 2011. Wages, productivity and employment: A review of theory and international data. European Employment Observatory Thematic expert ad-hoc paper. United Kingdom.

O Donnell, C., 2011. A Program for Decomposing Productivity Index Numbers. Brisbane: University of Queensland, Centre for Efficiency and Productivity Analysis.

O’Donnell, C., 2012. Applied Productivity and Efficiency Course Notes. Brisbane: University of Queensland, School of Economics Centre for Efficiency and Productivity Analysis.

O'Donnell, C. J., 2014. Econometric estimation of distance functions and associated measures of productivity and efficiency change. Journal of Productivity Analysis, 41, pp.187-200. doi: http://dx.doi.org/10.1007/s11123-012$\underline{0311-1}$

Parham, D. and Zheng, S., 2006. Aggregate and Industry Productivity Estimates for Australia. The Australian Economic Review, 39(2), pp.216-26. doi: http://dx.doi.org/10.1111/j.1467-8462.2006.00414.x

Productivity Commission, 2014. Public Infrastructure, Inquiry Report Volume 1, No. 71, Canberra.

Productivity Commission, 1999. Work Arrangements on Large Capital City Building Projects. Labour Market Research Report, Ausinfo, Canberra.

Rosenfielde, S. and Mills, D.Q., 1979. Is construction technologically stagnant? In: J.E. Lange and D.Q. Mills, eds. The Construction Industry. Lexington MA: D.C. Heath and Company.

Tan, W. 2000, Total Factor Productivity in Singapore Construction, Engineering, Construction and Architectural Management 2, 154-158. doi: http://dx.doi.org/10.1108/eb021140 and http://dx.doi.org/10.1046/j.1365232X.2000.00146.x

Toner, Phillip, Green, Roy, Croce, Nic and Mills, Bob, 2001. No Case to Answer: Productivity Performance of the Australian Construction Industry. Economic and Labour Relations Review, 12(1), pp.104-25. doi: http://dx.doi.org/10.1177/103530460101200107

Xue, X., Shen, Q., Wang, Y. and Lu. J. 2008, Measuring the Productivity of the Construction Industry in China by Using DEA-Based Malmquist Productivity Indices, Journal of Construction Engineering and Management, 134(1), 64-71. doi: http://dx.doi.org/10.1061/(ASCE)0733-9364(2008)134:1(64)

Yale University, 1997. Multiple Linear Regression. Available at: http://www.stat.yale.edu/Courses/199798/101/linmult.htm [Accessed 18 August 2015]. 